\title{
Morphology of the first larval stage of Macrobrachium brasiliense (Heller, 1868) (Caridea: Palaemonidae)
}

João Alberto Farinelli Pantaleão, Rafael Augusto Gregati, Fabiano Gazzi Taddei and Rogerio Caetano da Costa*

(JAFP, RCC) LABCAM (Laboratório de Biologia de Camarôes Marinhos e de Água Doce) Departamento de Ciências Biológicas, Faculdade de Ciências, UNESP, Campus Bauru, Av. Luis Edmundo Carrijo Coube, 14-01, Varjem Limpa, 17033-360 Bauru, SP, Brasil. E-mail: (JAFP) pantaleao@ibb.unesp.br; (RCC) rccosta@fc.unesp.br

(FGT) UNIRP (Centro universitário de Rio Preto) Departamento de Ciências Biológicas, Rua Yvette Gabriel Atique 45, 15025-400, São José do Rio Preto, SP, Brasil. E-mail: fgtaddei@hotmail.com (RAG) Departamento de Zoologia, Instituto de Biociências, UNESP, Campus Botucatu, Distrito de Rubião Jr, s/n, 18618-970 Botucatu, SP, Brasil. E-mail: gregati@ibb.unesp.br

NEBECC (Núcleo de Estudos em Biologia, Ecologia e Cultivo de Crustáceos)

*to whom correspondence should be sent

\section{Abstract}

In this paper, we describe and illustrate the morphology of the first larval stage of the prawn Macrobrachium brasiliense. Two ovigerous females were obtained in a stream environment, which belongs to Paraná River Basin, Southeastern of Brazil, and were maintained in laboratory until the time of hatching. The newly-hatched larva bears very advance morphological features, with benthic habits. They had sessile eyes and all appendages, except for the uropods; however, most of the appendages were not fully formed. The description given here is compared with the first larval stage of Macrobrachium species with abbreviated larval development from other localities.

Key words: Palaemonoidea, larval development, first zoea, abbreviated development, larval morphology

\section{Introduction}

The genus Macrobrachium (Bate, 1868) includes several species of prawns widely distributed in lakes, reservoirs, floodplains, and rivers in tropical and subtropical regions of South America, including all the main river basins (Orinoco, Amazon, Araguaia, Tocantins, São Francisco, Paraná, and Paraguay River basins), as well as the smaller rivers of the South Atlantic basin in the northern, northeastern, and eastern coasts of Brazil (Melo, 2003; Maciel and Valenti, 2009).
Most of the prawn species of economic importance belong to the genus Macrobrachium. They are widely exploited by artisan fisheries and used as protein sources by humans and other animals, and some species show a high potential for aquaculture. Besides economic factors, the Macrobrachium species have been shown to play important ecological roles (Magalhães, 2000; Magalhães et al., 2005). However, some of their biological characteristics are poorly understood.

Macrobrachium brasiliense (Heller, 1862) has a wide distribution in South America 
(Holthuis, 1952; Rodríguez, 1982; Coelho and Ramos-Porto, 1985; López and Pereira, 1996; Valencia and Campos, 2007), including the Peruvian Amazon basin (García-Dávila and Magalhães, 2003) and several states of Brazilian territory: Amapá, Amazonas, Bahia, Goiás, Maranhão, Mato Grosso, Mato Grosso do Sul, Minas Gerais, Pará, Paraná and São Paulo (Melo, 2003). Currently available studies on $M$. brasiliense cover mainly taxonomic and faunistic surveys (Holthuis, 1952; Kensley and Walker, 1982; Rodríguez, 1982; Coelho and Ramos-Porto, 1985; Magalhães, 2002; García-Dávila and Magalhães, 2003; Valencia and Campos, 2007), besides phylogeny (Murphy and Austin, 2005; Pileggi and Mantelatto, 2010). The knowledge about the species biology is very scarce (Mantelatto and Barbosa, 2005; Pereira and Chacur, 2009). In the northwest of São Paulo State, the species inhabits streams, in many cases highly impacted by agriculture action in the surrounding areas. The reproduction is markedly seasonal, closely related to the rainy season and ovigerous females are considerate very rare (Taddei, 2006).

According to García-Dávila and Magalhães (2003), the identification of $M$. brasiliense is performed based on the examination of adults, preferably the larger males. In this manner, the knowledge about the larval morphology of this species has a fundamental importance for the understanding of their biology, as well as for systematic and taxonomic studies. In this paper, the morphological description and illustrations of the first larval stage of $M$. brasiliense are provided, and comparisons are made between the first larval stage of this species from another locality (Vega-Pérez, 1984) and between the first larval stage of other species of the genus.

\section{Material and Methods}

In December 2009, two ovigerous females were obtained in a stream environment known as "Talhadinho" by locals due to proximity with the city of Talhados, São Paulo
State, Brazil (2047’07”S - 49²0'35”W). This stream belongs to the Paraná River Basin, Southeastern of Brazil. The collectors used a sieve ( $2 \mathrm{~mm}$ mesh diameter) near the margins (where there was some aquatic vegetation). The ovigerous females obtained were transported alive to the laboratory (Laboratório de Biologia do Centro Universitário de Rio Preto, UNIRP) in plastic containers with water from the collecting site and a small amount of aquatic plants or litter.

The females were kept isolated in 12 liters aquaria $(30 \times 20 \times 20 \mathrm{~cm})$ filled initially with water from the original environment; litter and small pieces of brick were added for shelter. The aquaria were under continuous moderated aeration supplied from an air compressor. One third of the water was replaced twice a week. The ovigerous prawns were fed in excess each afternoon with food for ornamental fish (Tetra Marine Flakes and Tetra Color) and bits of shrimp or fish muscle, squid, and bivalves. The leftover food at the following morning was siphoned out.

The newly hatched larvae were immediately fixed in $10 \%$ formalin and were transferred to a mixture $(1: 1)$ of $70 \%$ ethyl alcohol and glycerin. Because of the low number of hatched larvae (female one: 13 larvae and female two: 9 larvae) and the difficulty of collect ovigerous females, only the first larval stage was illustrated and preserved for future studies. Six larvae of each female were dissected for detailed examination and description.

The procedures for dissections and preparation for the illustration was based on Magalhães (1988). The larvae were left in water with $10 \%$ alcohol for approximately 20 minutes. Thereafter, it remained transparent for several hours. First stage larvae were dissected under a stereomicroscope and mounted under semi-permanent slides. Morphological characters were examined with a Zeiss Axioscop 2 compound microscope attached to a personal computer using an Axiovision Image Analysis system. A binocular microscope equipped with a "camera lucida" was used for the drawings. Total length (TL) is given as the distance from 
the tip of the rostrum to the posterior margin of the telson, excluding setae. Carapace length (CL) means the distance from the orbital angle to the posterior margin of the carapace. The entire process of description was standardized according to Pohle and Telford (1981) and Clark et al. (1998) with respect to the quality and terminology.

The two females and the first larval stage obtained of each were deposited in the larvae collection of the Núcleo de Estudos em Biologia, Ecologia e Cultivo de Crustáceos (NEBECC) under the number CAR0001.

\section{Results}

The first larval stage of $M$. brasiliense (Fig. 1) hatch as very advanced larvae, resembling the adults in many aspects. The larvae are benthic as soon as they hatch. In general, they differ from adults by the absence of free uropods, spatuleted telson and unarmed rostrum. In addition, the mouth parts, thoracic and abdominal appendix are not functional.

First larval stage (mean TL: $6.51 \mathrm{~mm}$; CL: $2.08 \mathrm{~mm})$

Body (Fig. 1): rostrum short, unarmed, strongly curved downwards. Carapace smooth. Eyes sessile. Abdomen smooth, segmentation between $6^{\text {th }}$ abdominal somite and telson
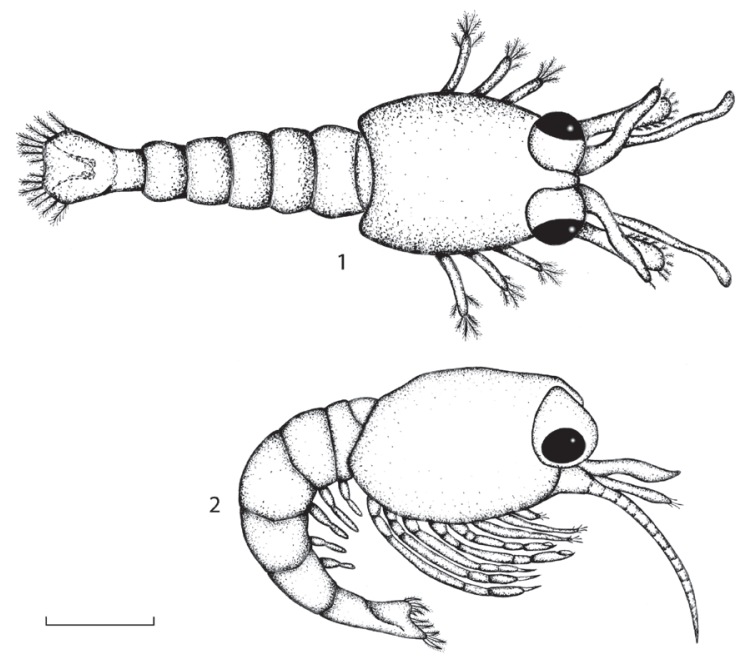

Figure 1. Macrobrachium brasiliense. Larva I. 1, Dorsal view; 2, Lateral view. $($ Scale $=1 \mathrm{~mm})$ not very distinct; ventral borders of pleurae incomplete.

Antennule (Fig. 2.3): peduncle long, unsegmented. Endopod with 1 short apical plumose setae, exopod longer than endopod, with 4 apical naked setae.

Antenna (Fig. 2.4): biramous. Peduncle unsegmented. Exopod (or scale) unsegmented, with external disto-lateral spine, 6 naked setae, and 10 plumose setae on distal margin. Endopod (or flagellum) has almost double size of exopod, with numerous joints and 3 short naked setae.

Mandible (Fig. 2.5): rudimentary, without palp. Incisor and molar processes not clearly defined.

Maxillula (Fig. 2.6): Rudimentary, unsegmented and smooth endopod. Coxal and basal endits with 3 and 4 distal protuberances.

Maxilla (Fig. 2.7): biramous. Protopod rudimentary. Endopod with 1 short curved naked setae. Exopod (escaphognathite) large, fringed by 36 plumose setae.

Maxilliped 1 (Fig. 2.8): biramous. Protopod unsegmented, with a bilobed, smooth epipodite. Endopod short, unsegmented, smooth. Exopod long, unsegmented, with 4 terminal plumose setae and 1 subterminal.

Maxilliped 2 (Fig. 2.9): biramous. Protopod unsegmented, smooth. Endopod 5-segmented, with 2 naked setae on propodus, dactylus hooked. Exopod unsegmented, with 4 terminal plumose setae and 1 subterminal.

Maxilliped 3 (Fig. 2.10): biramous. Protopod unsegmented. Endopod 5-segmented, with 2 naked setae on distal margin of propodus. Dactilus hooked. Exopod unsegmented, smaller than the endopod, with 6 plumose setae.

Pereiopods 1-2 (Fig. 2.11-12): well 


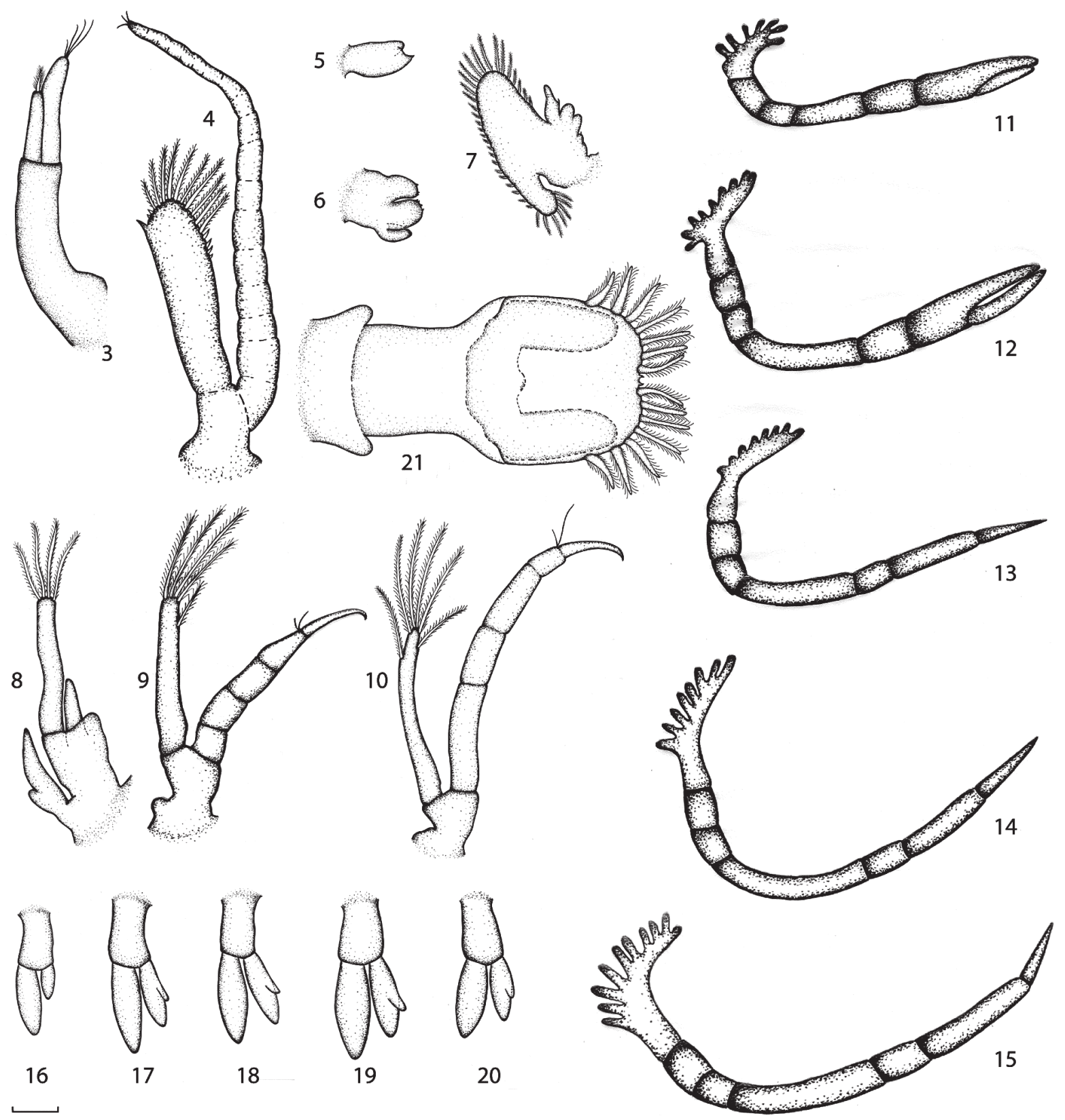

Figure 2. Macrobrachium brasiliense. Larva I. 3, Antennula; 4, Antenna; 5, Mandibule; 6, Maxillula; 7, Maxilla; 8-10, Maxilliped 1-3; 11-15, Pereiopods 1-5; 16-20, Pleopods 1-5; 21, Telson. $($ Scale $=0.2 \mathrm{~mm})$

developed, but not functional buds. Uniramous. Endopod glabrous, chelate, with distinct segmentation. Pereiopod 2 larger than pereiopod 1 .

Pereiopods 3-5 (Fig. 2.13-15): all as well developed buds. Uniramous, glabrous, with clear segmentation between joints.

Pleopods 1-5 (Fig. 2.16-20): All buds birramous and glabrous. Pleopod 1 the smallest; pleopods 2-5 with a rudimentary inner appendix in exopod.

Uropod (Fig. 2. 21): Not yet freed. Bud visible through the telson cuticle.

Telson (Fig. 2.21): fan-like. Posterior margin broadly convex, with $7+7$ plumose setae and pair of minute naked setae placed in a very faint median notch. 
Table 1. Comparison of the first larval stage for some Neotropical representatives of the genus Macrobrachium with abbreviated larval development already described.

\begin{tabular}{|c|c|c|c|c|c|c|c|}
\hline \multicolumn{2}{|c|}{ Authors of larval description } & \multirow{2}{*}{$\begin{array}{c}\text { Vega-Pérez (1984) } \\
\begin{array}{c}\text { Macrobrachium } \\
\text { brasiliense }\end{array}\end{array}$} & \multirow{2}{*}{$\begin{array}{c}\text { Magalhães (1989) } \\
\text { Macrobrachium nattereri }\end{array}$} & \multirow{2}{*}{$\begin{array}{c}\text { Bueno \& Rodrigues } \\
\text { (1995) } \\
\text { Macrobrachium } \\
\text { iheringi }\end{array}$} & \multirow{2}{*}{$\begin{array}{c}\text { Magalhães (2000) } \\
\text { Macrobrachium jelskii }\end{array}$} & \multirow{2}{*}{$\begin{array}{c}\text { Mejia-Ortiz et al. } \\
(2010)\end{array}$} & \multirow{2}{*}{$\begin{array}{c}\text { Present paper } \\
\begin{array}{c}\text { Macrobrachium } \\
\text { brasiliense }\end{array}\end{array}$} \\
\hline & & & & & & & \\
\hline Local & & Brazil, PR & Brazil, AM & Brazil, SP & Brazil, AM & Mexico, Oaxaca & Brazil, SP \\
\hline \multirow{2}{*}{ Size (mm) } & Carapace lenght & 2.003 & - & 1.49 & - & 2.09 & 2.08 \\
\hline & Total lenght & 5.146 & 4.98 & 4.7 & 5.95 & 5.95 & 6.51 \\
\hline Estructures & Characteristic & & & & & & \\
\hline Carapace & Spines & Absent & Absent & 1 , antennal & 1 , on anteroventral corner & Absent & Absent \\
\hline Abdomen & $\begin{array}{c}\text { Segmentaion between } \\
6^{\text {th }} \text { somite and telson }\end{array}$ & Present & Not very distinct & Present & Not very distinct & Present & Not very distinct \\
\hline Telson & $\mathrm{N}^{\circ}$ of plumose setae & $7+7$ & $\begin{array}{c}7+7+\text { a pair of minute } \\
\text { naked setae (median notch) }\end{array}$ & $\begin{array}{l}9+9+\text { a pair of minute } \\
\text { spines (median notch) }\end{array}$ & $9+9$ & 33 & $\begin{array}{c}7+7+\text { a pair of minute } \\
\text { naked setae (median } \\
\text { notch) }\end{array}$ \\
\hline \multirow[b]{2}{*}{ Antennula } & Inner flagela & 1 p. setae & 1 p.setae & 1 plumose setae & Simple and setaceous & 1 naked setae & 1 p. setae \\
\hline & Outer flagela & $\begin{array}{c}3 \text { aesthetes }+1 \mathrm{p} . \\
\text { setae }\end{array}$ & 3 naked setae & 1 naked setae & $\begin{array}{c}1 \text { p. setae }+1 \text { aesthete }+3 \\
\text { naked setae }\end{array}$ & 4 naked setae & 4 aesthetes \\
\hline Antenna & $\mathrm{N}^{\circ}$ of scale setae & $\begin{array}{c}12 \text { plumose }+1 \\
\text { spine }\end{array}$ & 11 plumose +3 naked & 11-12 plumose & 21 plumose & - & $\begin{array}{l}10 \text { plumose }+6 \text { naked }+1 \\
\text { spine }\end{array}$ \\
\hline \multirow[b]{2}{*}{ Mandible } & Palp & Absent & Absent & Absent & Absent & Absent & Absent \\
\hline & $\begin{array}{c}\mathrm{N}^{\circ} \text { of teeth } \\
\text { incisor/molar process }\end{array}$ & $0 / 0$ & $0 / 0$ & $1 / 0$ & $1 /$ some denticles & $1 / 0$ & $0 / 0$ \\
\hline \multirow{4}{*}{ Maxillula } & Endopod & Smooth & Smooth & Smooth & - & Smooth & Smooth \\
\hline & Basal endite & 2 spines & - & Smooth & - & - & 4 protuberances \\
\hline & Coxal endite & Smooth & - & Smooth & - & - & 3 protuberances \\
\hline & Protopod & Rudimentary & Rudimentary & Rudimentary & Rudimentary & - & Rudimentary \\
\hline \multirow{3}{*}{ Maxilla } & Endopod & $\begin{array}{l}\text { Unsegmented, } \\
\text { smooth }\end{array}$ & 1 spine & Unsegmented, 2 spines & Bilobed, 1 naked setae & - & $\begin{array}{l}\text { Unsegmented, } 1 \text { naked } \\
\text { setae }\end{array}$ \\
\hline & Escaphognathite & $\begin{array}{l}\text { 32-38 plumose } \\
\text { setae }\end{array}$ & - & 27-32 plumose setae & 12-13 plumose setae & 32 plumose setae & 36 plumose setae \\
\hline & Protopod & Rudimentary & Rudimentary & Rudimentary & Rudimentary & - & Rudimentary \\
\hline \multirow{3}{*}{$\begin{array}{c}\text { First } \\
\text { maxilliped }\end{array}$} & Endopod & 2 naked setae & Smooth & 3 naked setae & 4 plumose setae & - & Smooth \\
\hline & Exopod & 4 plumose setae & $\begin{array}{l}3 \text { plumose setae }+1 \text { naked } \\
+3 \text { p. setae in outer border }\end{array}$ & 6 plumose setae & 4 plumose setae & 4 plumose setae & 4 plumose setae \\
\hline & Protopod & Smooth & Smooth & Smooth & Smooth & Smooth & Smooth \\
\hline \multirow{3}{*}{$\begin{array}{l}\text { Second } \\
\text { Maxilliped }\end{array}$} & Endopod & $\begin{array}{l}\text { 5-segmented, } 4 \\
\text { naked setae }\end{array}$ & $\begin{array}{l}\text { 4-segmented, last seg with } \\
3 \text { naked setae }+1 \text { spine }\end{array}$ & $\begin{array}{l}\text { 4-segmented, dactyl with } \\
1 \text { spine }+2 \text { plumose setae }\end{array}$ & $\begin{array}{c}\text { Segmentation not distinct, } 1 \\
\text { spine }+5 \text { plumose setae }+1 \\
\text { naked setae }\end{array}$ & Unsegmented & $\begin{array}{c}\text { 5-segmented, } 2 \text { naked } \\
\text { setae }\end{array}$ \\
\hline & Exopod & 6 plumose setae & 5 plumose setae & 12 plumose setae & 9 plumose setae & 3 naked setae & 5 plumose setae \\
\hline & Protopod & $\begin{array}{l}\text { Unsegmented, } \\
\text { smooth }\end{array}$ & Bisegmented, smooth & Bisegmented, smooth & - & - & Unsegmented, smooth \\
\hline
\end{tabular}

Discussion

According to Jalihal et al. (1993), the larval development of Macrobrachium brasiliense corresponds to Type II: partially abbreviated development, with all pereiopods uniramous, well developed pleopods, and a fan-shaped telson in first stage. Other characteristics noted by Jalihal et al. (1993) for species with this kind of development (e.g., medium body size, distribution in upper reaches of rivers, and absence of marked sexual dimorphism) fit $M$. brasiliense well.

The larval characters of $M$. brasiliense described here suggests a closer relationship with $M$. nattereri (Heller, 1862) and $M$. iheringi (Ortman, 1897), both Neotropical species. These species have a morphologically similar first stage with uniramous pereiopods, biramous pleopods, and rounded telson (see Tab. 1). In addition, characteristics mentioned by Bueno and Rodrigues (1995) for $M$. iheringi from São Paulo State, as an unsegmented antennal scale, the numerous of marginal plumose setae in scaphognathite and six distinct abdominal somites are present in M. brasiliense.
Magalhães (1989), comparing the description done by Vega-Pérez (1984), had already mentioned that $M$. nattereri and $M$. brasiliense are closely related. They both occur in the Amazon basin and, in many cases even adult specimens are not easily identified. Although their larval development is similar in many respects, some differences can be mentioned in the first larval stage. In $M$. nattereri, the endopod of antenna, maxillipeds 2 and 3, and the pereiopods are unsegmented, while in $M$. brasiliense, these structures are clearly segmented. Yet, in the description performed by Vega-Pérez (1984), M. brasiliense has the $6^{\text {th }}$ abdominal somite clearly separated from the telson, while in $M$. nattereri this separation is indistinct. Both species have 7 +7 plumose setae on the posterior margin of telson, but in $M$. brasiliense this margin is clearly bilobed due to a distinct bulging of the disto-lateral corners (Magalhães, 1989).

However, the first zoea of $M$. brasiliense studied here, from northwest of São Paulo State, some characteristics resemble those of $M$. nattereri: the segmentation of the $6^{\text {th }}$ abdominal somite/telson is indistinct, the posterior margin of telson is not bilobed as was 
described by Vega-Pérez (1984), and there is a pair of minute naked setae placed in a very faint median notch of telson, which is very similar to $M$. nattereri.

Pileggi and Mantelatto (2010), studying the molecular phylogeny of the genus Macrobrachium based on direct optimization analysis of $16 \mathrm{~S}$ rDNA, used specimens of $M$. brasiliense from the São Paulo State (cities of Bauru and Serra-Azul) and M. nattereri from the Amazonas State (Manaus), and observed that the two species belong to sister groups, corroborating the conclusions drawn from larval morphology by Magalhães (1989) and now by the present study.

The wide distribution of $M$. brasiliense throughout tropical South America suggests that the populations occurring so far apart would exhibit some degree of morphological variation. Since the specimens of $M$. brasiliense studied by Vega-Pérez (1984) came from Paraná state, and in the present study, from São Paulo State, both Southeastern Brazil (Rio Paraná Basin), it would be interesting to verify how similar the larval morphology of the Central Amazonian population of $M$. brasiliense is to that one's already studied, as suggested by Magalhães (1989).

\section{Acknowledgments}

This research was supported by UNIRP (Centro Universitário de Rio Preto). The authors are indebted to Dr. Adilson Fransozo and Dr. Maria Lucia Negreiros-Fransozo for laboratorial assistance for drawings. The samplings were performed according to Brazilian State and Federal laws concerning wild animals.

\section{References}

Bueno, S.L.S. and Rodrigues, S.A. 1995. Abbreviated larval development of the freshwater prawn, Macrobrachium iheringi (Ortmann, 1897) (Decapoda, Palaemonidae), reared in the laboratory. Crustaceana, 68(6): 665-686.
Clark, P.F.; Calazans, D.K. and Pohle, G.W. 1998. Accuracy and standardization of Brachyuran larval descriptions. Invertabrate Reproduction and Development, 33: 127144.

Coelho, P.A. and Ramos-Porto, M. 1985. Camarôes de água doce do Brasil: Distribuição geográfica. Revista Brasileira de Zoologia, 2: 405-410.

García-Dávila, C.R. and Magalhães, C. 2003. Revisão taxonômica dos camarôes de água doce (Crustacea, Decapoda, Palaemonidae, Sergestidae) da Amazônia Peruana. Acta Amazonica, 33(4): 663-686.

Holthuis, L.B. 1952. A general revision of the Palaemonidae (Crustacea, Decapoda, Natantia) of the Americas. II. The subfamily Palaemonidae. Occasional Papers of the Allan Hancock Foundation, 12: 1-396.

Jalihal, D.R.; Sankolli, K.N. and Shenoy, S. 1993. Evolution of larval developmental patterns and the process of freshwaterization in the prawn genus Macrobrachium Bate, 1868 (Decapoda, Palaemonidae). Crustaceana, 65: 365-376.

Kensley, B. and Walker, I. 1982. Palaemonid shrimps from the Amazon Basin, Brazil (Crustacea: Decapoda: Natantia). Smithsonian Contributions to Zoology, 362: 1-18.

Lopez, B. and Pereira, G. 1996. Inventario de los crustáceos decapodos de las zonas alta y media del delta del Rio Orinoco, Venezuela. Acta Biologica Venezuelica, 16(3):45-64.

Maciel, C.R. and Valenti, W.C. 2009. Biology, Fisheries, and Aquaculture of the Amazon River Prawn Macrobrachium amazonicum: A Review. Nauplius, 17(2): 61-79.

Magalhães, C. 1988. The larval development of palaemonid shrimps from the Amazon region reared in the laboratory. II. Extremely abbreviated development in Euryrhyncus Miers, 1877 (Decapoda, Euryrhynchinae). Crustaceana, 55(1): 39-52.

Magalhães, C. 1989. The larval development of palaemonid shrimps from the Amazon region reared in the laboratory. Abbreviated development of Macrobrachium nattereri (Heller, 1862) (Crustacea: Decapoda). 
Amazoniana, 10: 379-392.

Magalhães, C. 2000. Abbreviated larval development of Macrobrachium jelskii (Miers, 1877) (Crustacea: Decapoda: Palaemonidae) from the Rio Solimóes floodplain, Brazil, reared in the laboratory. Nauplius, 8(1): 1-14.

Magalhães, C. 2002. A rapid assessment of the decapod fauna in the Rio Tahuamanu and Rio Manuripi Basins, with new records of shrimps and crabs for Bolivia (Crustacea, Decapoda, Palaemonidae, Sergestidae, Trichodactylidae). Revista Brasileira de Zoologia, 19(4): 1091-1103.

Magalhães, C.; Bueno, S.L.S.; Bond-Buckup, G.; Valenti, W.C.; Silva, H.L.M.; Kiyohara, F.; Mossolin, E.C. and Rocha, S.S. 2005. Exotic species of freshwater decapod crustaceans in the state of Sao Paulo, Brazil: records and possible causes of their introduction. Biodiversity and Conservation, 14: 1929-1945.

Mantelatto, F.L. and Barbosa, L.R. 2005. Population structure and relative growth of freshwater prawn Macrobrachium brasiliense (Decapoda, Palaemonidae) from São Paulo State, Brazil. Acta Limnologica Brasiliensia, 17(3): 245-255.

Mejía-Ortíz, L.M.; Hartnoll, R.G. and López-Mejía, M. 2010. The abbreviated larval development of Macrobrachium totonacum Mejía, Alvarez \& Hartnoll, 2003 (Decapoda, Palaemonidae), reared in the laboratory. Crustaceana, 83(1): 1-16.

Melo, G.A.S. 2003. Manual de identificação dos Crustacea Decapoda de água doce do Brasil. Loyola, São Paulo, 420 p.

Murphy, N.P. and Austin, C.M. 2005. Phylogenetic relationships of the globally distributed freshwater prawn genus Macrobrachium (Crustacea: Decapoda: Palaemonidae): biogeography, taxonomy and the convergent evolution of abbreviated larval development. Zooloogica Scripta, 34(2): 187-197.

Pereira, M.G.C. and Chacur, M.M. 2009. Estrutura populacional de Macrobrachium brasiliense (Crustacea, Palaemonidae) do Córrego Escondido, Batayporã, Mato
Grosso do Sul, Brasil. Revista de Biologia Neotropical, 6(1): 75-82.

Pileggi, L.A. and Mantelatto, F.L. 2010. Molecular phylogeny of the freshwater prawn genus Macrobrachium (Decapoda, Palaemonidae), with emphasis on the relationships among selected American species. Invertebrate Systematics, 24(1): 194208.

Pohle, G.W. and Telford, M. 1981. Morphology and classification of decapod crustacean larval cerdae: a scanning electron microscope study of Dissodactylus crinitichelis Moreira, 1901 (Brachyura: Pinnotheridae). Bulletin of Marine Science, 31: 736-752.

Rodriguez, G. 1982. Freshwater shrimps (Crustacea, Decapoda, Natantia) of the Orinoco basin and the Venezuelan Guayana. Journal of Crustacean Biology, 2(3): 378-391.

Taddei, F.G. 2006. Biologia populacional, reprodutiva e crescimento dos camaróes Palemonídeos Macrobrachium jelskii (Miers, 1877) e Macrobrachium brasiliense (Heller, 1868) (Crustacea: Caridea) na regiáo nordeste do Estado de São Paulo. PhD Thesis. Instituto de Biociências, UNESP, Botucatu, São Paulo. 217 p.

Valencia, D.M. and Campos, M.R. 2007. Freshwater prawns of the genus Macrobrachium Bate, 1868 (Crustacea: Decapoda: Palaemonidae) of Colombia. Zootaxa, 1456:1-44.

Vega-Pérez, L.A. 1984. Desenvolvimento larval de Macrobrachium heterochirus (Wiegmenn, 1836), Macrobrachium amazonicum (Heller, 1862) e Macrobrachium brasiliense (Heller, 1862) (Crustacea, Decapoda, Palaemonidae), em laboratório. PhD Thesis, Universidade de São Paulo, São Paulo. 277 p. (Unpublished)

Submitted 08 April 2011 Accepted 26 July 2011 